\title{
Effects of cholinergic and adrenergic drugs on intraluminal pressures and contractility of the rat testis and epididymis in vivo
}

\author{
C. Pholpramool and N. Triphrom* \\ Department of Physiology, Faculty of Science, Mahidol University, Rama VI Road, Bangkok 10400, \\ Thailand
}

\begin{abstract}
Summary. Intravenous administration of methacholine $(200 \mu \mathrm{g} / \mathrm{kg})$ caused no changes in the seminiferous tubules of rats, but significantly increased intraluminal pressures and contractility of the caput, the corpus and the cauda epididymidis. The effect of methacholine was abolished by pretreatment with atropine $(500 \mu \mathrm{g} / \mathrm{kg})$, but not by phentolamine $(400 \mu \mathrm{g} / \mathrm{kg})$ or propranolol $(400 \mu \mathrm{g} / \mathrm{kg})$. Adrenaline $(5-40 \mu \mathrm{g} / \mathrm{kg})$, noradrenaline $(5-40 \mu \mathrm{g} / \mathrm{kg})$ and phenylephrine $(100-400 \mu \mathrm{g} / \mathrm{kg})$ had no effect on the seminiferous tubules, but dose-dependently elevated intraluminal pressures and enhanced the contractility of all regions of the epididymis. Isoproterenol (100-800 $\mu \mathrm{g} / \mathrm{kg}$ ) did not affect intraluminal pressures of the seminiferous tubules and the epididymal duct. The stimulatory effect of adrenergic agonists was specifically blocked by phentolamine, but not by propranolol or atropine. Cholinergic and adrenergic antagonists did not alter spontaneous contraction of the epididymis. The results suggest that the contractility of all segments of the rat epididymis, but not the seminiferous tubules, can be increased by autonomic drugs. The enhancing effect of adrenergic drugs is probably the result of activation through $\alpha$-adrenergic receptors.
\end{abstract}

\section{Introduction}

Transport of spermatozoa through the epididymis is mainly the result of spontaneous contractions of the smooth muscle enveloping the epididymal duct and the presence of cholinergic and adrenergic nerve terminals in this tissue has been demonstrated (Hodson, 1970). The different regions of the epididymis, in many animals, receive a dual cholinergic and adrenergic innervation, although the relative abundance and arrangement of nerve fibres vary in different areas. However, the role of neural elements in duct motility is unclear. Only a few attempts have been made to study the effect of direct nerve stimulation or denervation on the contractility of the epididymis (Hib, Ponzio \& Vilar, 1979, 1982). Functions of the nerve fibres in controlling smooth muscles of the epididymal duct are derived primarily from pharmacological studies. Cholinergic and adrenergic drugs increase contractility of the isolated cauda epididymidis of mice (Hib \& Caldeyro-Barcia, 1974) and rats (Laitinen \& Talo, 1981). The stimulatory effect of several adrenergic agonists has been mainly attributed to the activation through $\alpha$-receptors. However, both $\alpha$ - and $\beta$-receptors appear to be present in the rat cauda epididymidis in vivo (Hib, 1976). The nature of adrenergic receptors in the rat cauda epididymidis is still controversial. There has been no quantitative study on the responsiveness of the proximal regions of the epididymis to pharmacological agents,

* Present address: Department of Obstetrics and Gynecology, Faculty of Nursing, Chiangmai University, Chiangmai, Thailand.

(C) 1984 Journals of Reproduction \& Fertility Ltd 
although such a study of the seminiferous tubules (isolated mass of testicular parenchyma) of rats and rabbits has been reported (Davis \& Langford, 1971).

The contractility of different regions of the epididymis can be studied by micropuncture using a servo-nulling transducer system (Pholpramool, Triphrom \& Din-Udom, 1984). In the present investigation, we employed the same method to study the effects of autonomic drugs on intraluminal pressures and contractility of the seminiferous tubules and different regions in the epididymis of rats in vivo. The nature of the adrenergic receptors in the epididymal duct was also investigated.

\section{Materials and Methods}

\section{Animals}

Adult, male albino rats of the Fischer strain, weighing $250-300 \mathrm{~g}$, were housed in groups of 6-8, separate from females, and with $14 \mathrm{~h} \mathrm{light} / 24 \mathrm{~h}$ and free access to food and water. The animals were fasted overnight and were anaesthetized with an intraperitoneal injection of sodium 5-ethyl-5-(1methyl propyl)-2-thiobarbiturate (Inactin: Byk Gulden Konstanz, West Germany) at a dose of 100 $\mathrm{mg} / \mathrm{kg}$ body weight. After surgical anaesthesia was induced, the rats were placed on a warm operating board, and tracheostomy was performed to facilitate aspiration of bronchial secretion which occasionally blocked the respiratory airways. The carotid artery on one side and external jugular vein on the other side were exposed and catheterized with polyethylene tubings (PE-50 for the artery and PE-10 for the vein: Clay-Adams) for continuous monitoring of arterial blood pressure and for administration of drugs, respectively. Body temperature of the animals was maintained at $37^{\circ} \mathrm{C}$ by a telethermometer (Model 43TD, Yellow-Springs, U.S.A.) using a rectal probe and a direct illumination.

\section{Micropuncture and measurements of intraluminal pressure}

The testis and the epididymis were prepared for micropuncture and intraluminal pressure measurements as previously described (Pholpramool et al., 1984). The sites of pressure measurements in the epididymis were the mid-caput (site 2 ), the mid-corpus (site 4 ) and the proximal cauda (site 6).

\section{Experimental procedure}

Experiment 1 . The effects of a cholinergic agonist (methacholine) and antagonist (atropine) were studied in 6 rats. A dose of methacholine $(200 \mu \mathrm{g} / \mathrm{kg})$ was administered through the jugular venous catheter after a steady intraluminal pressure recording was established for at least 5 min. Pressure measurement was continued until the effect of methacholine had subsided. The micropipette was then withdrawn. The experiment was repeated in another area: 4 areas were measured in each rat, and the sequence of micropuncture in each animal was random. Atropine $(500 \mu \mathrm{g} / \mathrm{kg}) \mathrm{was}$ intravenously injected approximately $1 \mathrm{~min}$ before the last dose of methacholine for each rat. In some experiments adrenergic antagonists were also given to test whether the effect of methacholine occurred via an increase in sympathetic activity as a consequence of a generalized decrease in systemic arterial pressure. In these experiments, the antagonists were also administered just before the conclusion of the experiments.

Experiment 11 . The effect of adrenergic agonists (adrenaline, noradrenaline, phenylephrine and isoproterenol) and antagonists (phentolamine and propranolol) was studied in 27 rats. The experimental procedure was similar to that described in Exp. I, except that 3-4 doses of each agonist were given in an increasing dose to obtain a dose-response curve and only 2 areas of the genital duct were measured in each animal. 
All drugs were freshly prepared in saline $(9 \mathrm{~g} \mathrm{NaCl} / 1)$ at $\mathrm{pH} 7 \cdot 4$ and were given in a volume of $0 \cdot 1$ $\mathrm{ml}$. The choice of doses used was based on previous in-vivo study (Hib, 1976). Injection of saline had no effect on the pressure recordings in any experiment.

\section{Chemicals}

(-)Adrenaline and (-)noradrenaline bitartrate were purchased from Nutritional Biochemicals, Cleveland, OH, U.S.A. Propranolol hydrochloride (Inderal) was obtained from Imperial Chemical Industries, Macclesfield, U.K. Phentolamine hydrochloride was a gift from Ciba, Summit, NJ, U.S.A. (-)Phenylephrine hydrochloride, $( \pm$ )isoproterenol hydrochloride, methacholine chloride (acetyl- $\beta$-methylcholine chloride) and atropine sulphate were supplied by Sigma, St Louis, MO, U.S.A.

\section{Statistical analyses}

Comparisons within a group and amongst different groups were made by using Student's $t$ test for paired data and analysis of variance, respectively. A difference was considered significant if $\mathbf{P}<0.05$. All data are presented as mean \pm s.e.m.

\section{Results}

\section{Effect of cholinergic agonist and antagonist}

Seminiferous tubules. Intraluminal pressure in the seminiferous tubules during the control period was $2.5 \pm 0.3(n=6) \mathrm{cmH}_{2} \mathrm{O}$. As previously reported (Pholpramool et al., 1984), there were no rhythmic contractions. Administration of methacholine $(200 \mu \mathrm{g} / \mathrm{kg})$ had virtually no effect on the pressure recording of the seminiferous tubules (Text-fig. 1), although a marked decrease in systemic arterial blood pressure occurred, i.e. from $122 \cdot 5 \pm 6$ to $42 \pm 4 \mathrm{mmHg}$. Pretreatment with atropine $(500 \mu \mathrm{g} / \mathrm{kg})$ did not modify the intratubular hydrostatic pressure of the seminiferous tubules, but did abolish the effect of methacholine on the arterial blood pressure.

Epididymal duct. Methacholine $(200 \mu \mathrm{g} / \mathrm{kg})$ produced a slight but significant increase in basal pressure and frequency, but not in amplitude, of contraction in the mid-caput and the mid-corpus (Table 1). On the other hand, a 2.5-fold increase in basal pressure of the proximal cauda occurred whilst there was no change in the frequency of contraction. The amplitude of contraction in this area of the epididymis was decreased during a marked elevation in basal pressure. The effect of methacholine on the intraluminal pressure and contractility of the epididymal duct lasted for 2-3 min.

Injection of atropine $(500 \mu \mathrm{g} / \mathrm{kg})$ did not alter intraluminal pressure or the spontaneous contractility of any region of the epididymis, but did block completely the effect of methacholine. Pretreatment with phentolamine $(400 \mu \mathrm{g} / \mathrm{kg})$ or propranolol $(400 \mu \mathrm{g} / \mathrm{kg})$ failed to alter the responses of the tubule to methacholine, indicating that the effect of methacholine was not the result of a reflex increase in sympathetic activity during a substantial fall in blood pressure.

\section{Effect of adrenergic agonists and antagonists}

Seminiferous tubules. The adrenergic drugs (adrenaline and noradrenaline at doses of 5, 10, 20 and $40 \mu \mathrm{g} / \mathrm{kg}$; phenylephrine, at doses of 100,200 and $400 \mu \mathrm{g} / \mathrm{kg}$; isoproterenol, at doses of 100,400 and $800 \mu \mathrm{g} / \mathrm{kg}$ ) and adrenergic blockers (phentolamine, $400 \mu \mathrm{g} / \mathrm{kg}$; propranolol, $400 \mu \mathrm{g} / \mathrm{kg}$ ) had no effect on intraluminal pressure of the seminiferous tubules (Text-fig. 1).

Epididymal duct. Significant increases in basal pressure and frequency of contractions in all regions of the epididymis occurred after intravenous injection of adrenaline or noradrenaline. The 


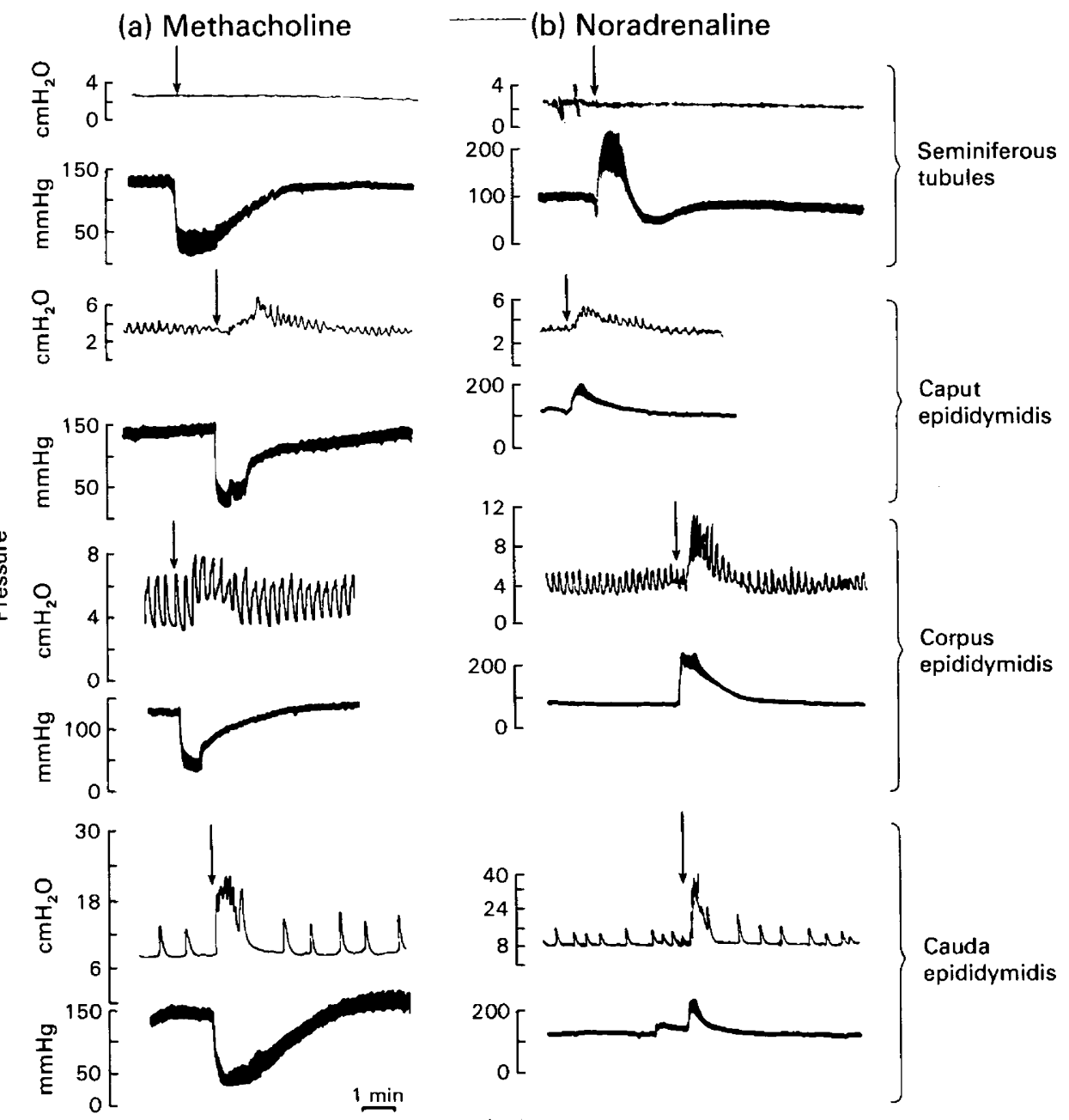

Text-fig. 1. A representative recording of intraluminal pressures $\left(\mathrm{cmH}_{2} \mathrm{O}\right)$ in the seminiferous tubules and in the mid-caput, the mid-corpus and the proximal cauda epididymidis, and systemic arterial pressure $(\mathrm{mmHg}$ ) of a rat showing the effect of injection (arrows) of (a) $200 \mu \mathrm{g}$ methacholine $/ \mathrm{kg}$, or (b) $20 \mu \mathrm{g}$ noradrenaline $/ \mathrm{kg}$.

Table 1. Effect of methacholine $(200 \mu \mathrm{g} / \mathrm{kg}$, i.v.) on the intraluminal pressure and contractility of the rat epididymis (for sites of pressure measurements see Pholpramool et al., 1984)

\begin{tabular}{|c|c|c|c|c|c|c|}
\hline \multirow[b]{3}{*}{ Epididymal sites } & \multirow{2}{*}{\multicolumn{2}{|c|}{$\begin{array}{l}\text { Intraluminal basal } \\
\text { pressure }\left(\mathrm{cmH}_{2} \mathrm{O}\right)\end{array}$}} & \multicolumn{4}{|c|}{ Contraction } \\
\hline & & & \multicolumn{2}{|c|}{ Amplitude $\left(\mathrm{cmH}_{2} \mathrm{O}\right)$} & \multicolumn{2}{|c|}{ Frequency/min } \\
\hline & $\begin{array}{l}\text { Before } \\
\text { drug }\end{array}$ & $\begin{array}{l}\text { After } \\
\text { drug }\end{array}$ & $\begin{array}{l}\text { Before } \\
\text { drug }\end{array}$ & $\begin{array}{l}\text { After } \\
\text { drug }\end{array}$ & $\begin{array}{l}\text { Before } \\
\text { drug }\end{array}$ & $\begin{array}{l}\text { After } \\
\text { drug }\end{array}$ \\
\hline Mid-caput & $2 \cdot 7 \pm 0.2$ & $3 \cdot 6 \pm 0 \cdot 4^{* *}$ & $1.7 \pm 0.4$ & $1.9 \pm 0.2$ & $3 \cdot 8 \pm 0.4$ & $5 \cdot 2 \pm 0 \cdot 2^{* *}$ \\
\hline Mid-corpus & $4 \cdot 2 \pm 0 \cdot 6$ & $5 \cdot 3 \pm 0 \cdot 3^{*}$ & $3 \cdot 1 \pm 0 \cdot 4$ & $3.0 \pm 0.4$ & $3 \cdot 0 \pm 0 \cdot 3$ & $4 \cdot 1 \pm 0 \cdot 3^{*}$ \\
\hline Proximal cauda & $6 \cdot 3 \pm 1 \cdot 2$ & $17 \cdot 5 \pm 2 \cdot 3^{* *}$ & $18 \cdot 3 \pm 1 \cdot 0$ & $12 \cdot 0 \pm 1 \cdot 2^{* *}$ & $1 \cdot 3 \pm 0 \cdot 2$ & $1.4 \pm 0.4$ \\
\hline
\end{tabular}

Values are mean \pm s.e.m. from 6 rats.

Significantly different from the control value: ${ }^{*} P<0.01,{ }^{*} P<0.001$. 

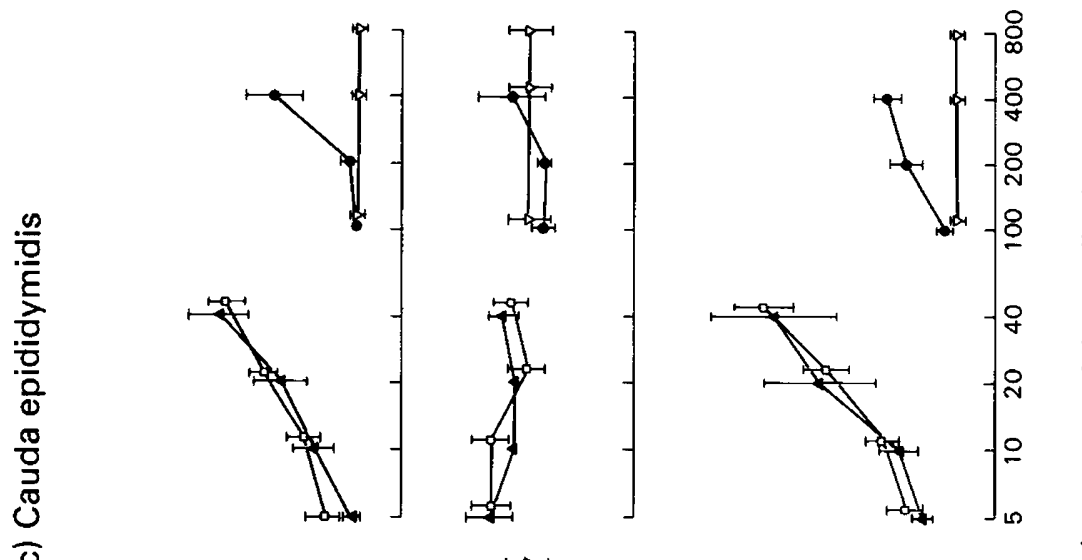

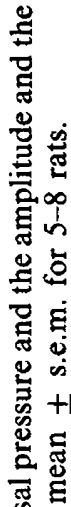

ত
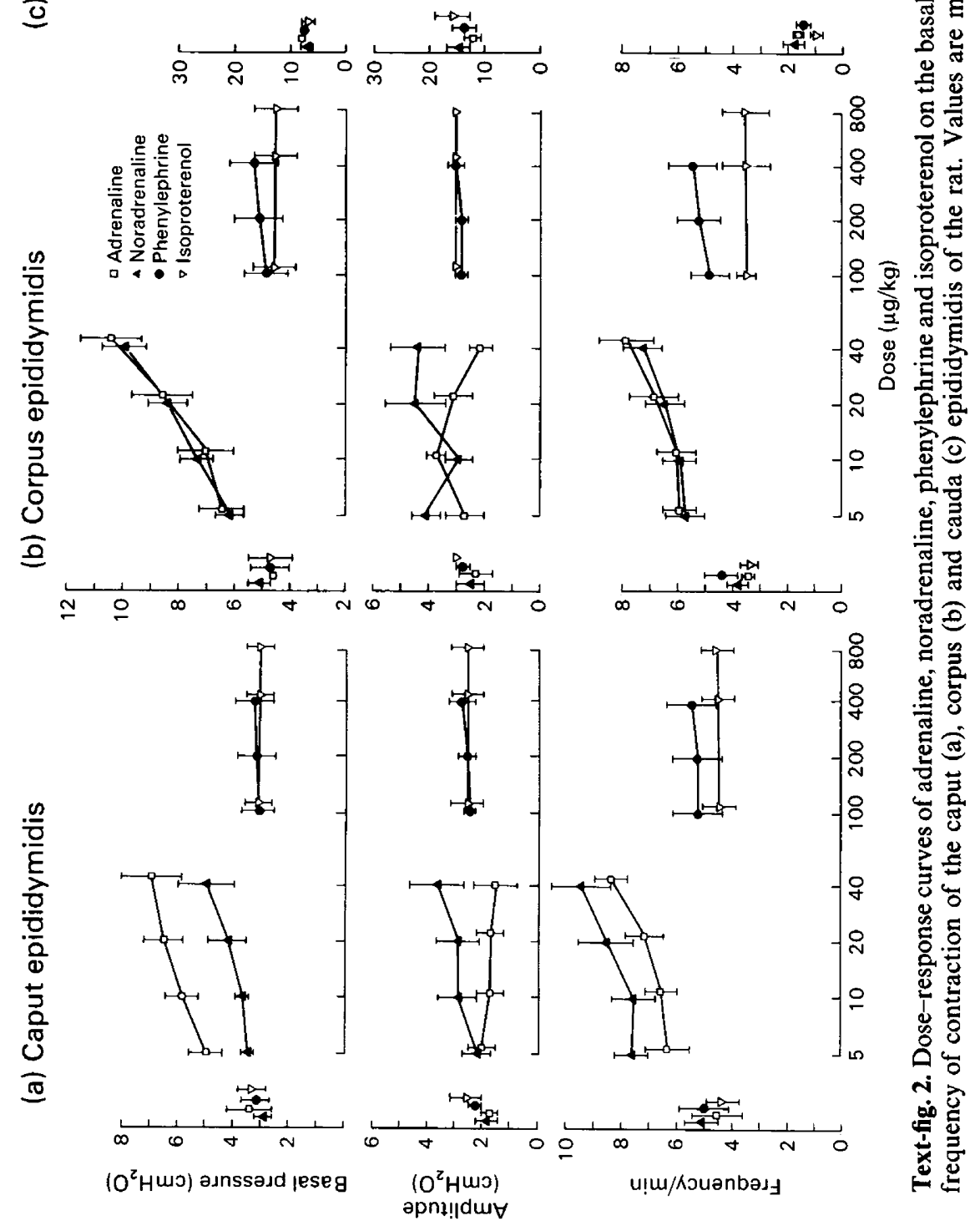
dose-response curves of these drugs were linear over a dose range from 5 to $40 \mu \mathrm{g} / \mathrm{kg}$ (Text-fig. 2). The amplitude of contraction was also heightened, but to a lesser extent. However, an increment in the amplitude was apparently not dose-related except for the effect of noradrenaline on the midcaput (Text-fig. 2a). Although there was a tendency for phenylephrine to exert similar effects, significant changes $(P<0.001)$ were noted only in the proximal cauda and only when the dose of phenylephrine was $>200 \mu \mathrm{g} / \mathrm{kg}$ (Text-fig. 2c). All regions of the epididymis appeared to be unresponsive to isoproterenol, even at a dose as high as $800 \mu \mathrm{g} / \mathrm{kg}$. Therefore the potency of the adrenergic agonists in enhancing contractility of the rat epididymis is in the order: adrenaline $>$ noradrenaline $>$ phenylephrine $>$ isoproterenol.

The effects of adrenaline, noradrenaline and phenylephrine were completely prevented by pretreatment with phentolamine $(400 \mu \mathrm{g} / \mathrm{kg})$, but not by propranolol $(400 \mu \mathrm{g} / \mathrm{kg})$ or atropine $(500$ $\mu \mathrm{g} / \mathrm{kg}$ ). The adrenergic antagonists caused no changes in basal pressure and spontaneous contractions in any region of the epididymis.

\section{Discussion}

The results show that rat seminiferous tubules do not respond to cholinergic or adrenergic drugs although these agents significantly enhanced the contractility of all regions of the epididymis. This confirms previous work that demonstrated a lack of effect of various autonomic drugs on the decapsulated testicular parenchyma of rats and rabbits (Davis \& Langford, 1971). There are several reasons to believe that an elevation in basal pressure of the epididymis induced by autonomic agents is the result of contraction of smooth muscles supporting the epididymal duct rather than an increase in intraluminal fiuid volume. First, the time to peak response is relatively fast $(<30 \mathrm{sec})$. Secondly, the effect of all drugs increases from the caput to the cauda, findings that correspond with the increase in the thickness of smooth muscles of the epididymal duct from the proximal towards the distal segment (Hamilton, 1975). The influence of autonomic drugs on fluid secretion in the epididymis is not known. On the other hand, it has been shown that fluid reabsorption in the isolated rat cauda epididymidis is enhanced by $\beta$-adrenergic agonists, but inhibited by $\alpha$-adrenergic agonists (Wong \& Yeung, 1978). Luminal fluid content would, therefore, be decreased by activation of $\beta$-receptors and increased by stimulation of $\alpha$-receptors. However, this change could not account for the present findings.

The increase in contractility of the cauda epididymidis in response to cholinergic and adrenergic agonists is, in general, consistent with other studies of the ram (Knight, 1974), mouse (Hib \& Caldeyro-Barcia, 1974), guinea-pig (Da Silva E Souza, Gemino \& Gemino, 1975), and rat (Hib, 1976; Laitinen \& Talo, 1981). The effect of systemic administration of cholinergic or adrenergic agents on tubular contractility is not due to refiex changes in activity of the autonomic nerves as a result of changes in arterial blood pressure, because the responses to cholinergic or adrenergic agonists are not altered by adrenergic or cholinergic antagonists, respectively.

The pattern of innervation of the male genital duct varies in different regions and in different species (Hodson, 1970). In most mammals, the genital duct from the seminiferous tubules to the mid-corpus epididymidis has little or no innervation. The cauda epididymidis, on the other hand, receives a rich supply of cholinergic and adrenergic nerves. That the caput and the corpus are responsive to cholinergic as well as adrenergic drugs indicates that cholinergic (muscarinic) and adrenergic receptors are present in this region of the epididymis in the rat. The results appear to be at variance with those of histochemical studies (Risley \& Skrepetos, 1964; El-Badawi \& Schenk, 1967). The presence of pharmacological receptors in spite of the lack of evidence for innervation suggests that humoral agents may be a major factor controlling contractility of the proximal region of the epididymis compared to the distal segment. In support of this hypothesis, Ratnasooriya, Gilmore \& Wadsworth (1980) showed that a Silastic implant containing methoxamine (an $\alpha$ adrenergic agonist), but not tyramine or norephedrine (indirectly sympathomimetic), near the 
epididymis produced rapid infertility in the male rat. This has been ascribed to acceleration of sperm transport especially in the proximal region of the epididymis.

The responsiveness of the epididymis to various adrenergic drugs reveals that those agents with a predominantly $\alpha$-receptor activity (adrenaline, noradrenaline and phenylephrine) are more potent than the pure $\beta$-activator (isoproterenol). In addition, only the $\alpha$-blocker (phentolamine) was effective in preventing the effect of adrenergic agonists. These results all indicate that the enhancing effect of the adrenergic drugs used in this study with the rat epididymis occurs through activation of only $\alpha$-receptors, as found for the isolated cauda epididymidis of the mouse (Hib \& Caldeyro-Barcia, 1974) and the rat (Laitinen \& Talo, 1981). However, Hib (1976) reported that the contractility of the rat cauda epididymidis in vivo was enhanced by activation of $\alpha$ - or $\beta$-receptors, although the $\beta$-stimulant (orciprenaline) used by Hib (1976) was much less effective than adrenaline or noradrenaline. Since orciprenaline is a long-acting derivative of isoproterenol, a discrepancy in the results may be quantitative rather than qualitative. Both types of adrenergic receptors may exist in the rat epididymis, but the $\alpha$-receptors may predominate with respect to numbers of receptor sites and/or reactivity between receptors and stimulants.

The role of autonomic nerves in controlling spontaneous contractions of the epididymis is unknown. However, there is evidence indicating that spontaneous activity of the rat epididymal duct is independent of adrenergic innervation since the motility appears to be normal after pharmacological denervation by guanethidine (Hib et al., 1979). The lack of effect of cholinergic and adrenergic antagonists on spontaneous contractions in the present study and in those of Hib \& Caldeyro-Barcia (1974) and Laitinen \& Talo (1981) suggests that spontaneous activity is myogenic in origin. On the other hand, the autonomic nerves, particularly the adrenergic fibres, play an important role in initiating a sudden and strong contraction of the distal part of the epididymis and the vas deferens which is responsible for discharge of spermatozoa at ejaculation (Baumgarten, Holstein \& Rosengren, 1971).

We thank Miss Suthada Homjun for secretarial assistance. This investigation received financial support from the Special Programme of Research, Development and Research Training in Human Reproduction, World Health Organisation.

\section{References}

Baumgarten, H.G., Holstein, A.F. \& Rosengren, E. (1971) Arrangement, ultrastructure, and adrenergic innervation of smooth musculature of the ductuli efferentes, ductus epididymis and ductus deferens of man. Z. Zellforsch. mikrosk. Anat. 120, 37-79.

Da Silva E Souza, M.C., Gemino, M.F. \& Gemino, A.L. (1975) Physiologic and pharmacologic studies on the motility of isolated guinea pig cauda epididymidis. Fert. Steril. 26, 1250-1256.

Davis, J.R. \& Langford, G.A. (1971) Comparative responses of the isolated testicular capsule and parenchyma to autonomic drugs. J. Reprod. Fert. 26, 241-245.

El-Badawi, A.\& Schenk, E.A. (1967) The distribution of cholinergic and adrenergic nerves in the mammalian epididymis: a comparative histochemical study. $A m$. J. Anat. 121, 1-14.

Hamilton, D.W. (1975) Structure and function of the epithelium lining the ductuli efferentes, ductus epididymis, and ductus deferens in the rat. In Handbook of Physiology, Vol. V, Endocrinology. Section 7, Male Reproductive System, pp. 259-301. Eds D. W. Hamilton \& R. O. Greep. Am. Physiol. Soc., D.C.
Hib, J. (1976) Effects of autonomic drugs on epididymal contractions. Fert. Steril. 27, 951-956.

Hib, J. \& Caldeyro-Barcia, R. (1974) Neurohormonal control of epididymal contractions. In Physiology and Genetics of Reproduction, Part B, pp. 111-126. Eds E. M. Coutinho \& F. Fuchs. Plenum Press, New York.

Hib, J., Ponzio, R.O. \& Vilar, O. (1979) Contractile behaviour of rat epididymis after sympathectomy produced by the administration of guanethidine. Andrologia 11, 461-465.

Hib, J., Ponzio, R.O. \& Vilar, O. (1982) Contractility of the rat cauda epididymidis and vas deferens during seminal emission. J. Reprod. Fert. 66, 47-50.

Hodson, N. (1970) The nerves of the testis, epididymis and scrotum. In The Testis, Vol. I, pp. 47-99. Eds A. D. Johnson, W. R. Gomes \& N. L. VanDemark. Academic Press, New York.

Knight, T.W. (1974) A qualitative study of factors affecting the contractions of the epididymis and ductus deferens of the ram. J. Reprod. Fert. 40, 139-145.

Laitinen, L. \& Talo, A. (1981) Effects of adrenergic and cholinergic drugs on electrical and mechanical activities of the rat cauda epididymidis in vitro. $J$. Reprod. Fert. 63, 205-209. 
Pholpramool, C., Triphrom, N. \& Din-Udom, A. (1984) Intraluminal pressures in the seminiferous tubules and in different regions of the epididymis in the rat. J. Reprod. Fert. 71, 173-179.

Ratnasooriya, W.D., Gilmore, D.P. \& Wadsworth, R.M. (1980) Effect of local application of sympathomimetic drugs to the epididymis on fertility in rats. $J$. Reprod. Fert. 58, 19-25.
Risley, P.L. \& Skrepetos, C.N. (1964) Histochemical distribution of cholinesterases in the testis, epididymis and vas deferens of the rat. Anat. Rec. 148, 231248.

Wong, P.Y.D. \& Yeung, C.H. (1978) Effects of catecholamines and adrenergic blockade on fluid reabsorption in isolated rat cauda epididymidis. Japan. $J$. Pharmacol. 28, 115-123.

Received 2 September 1983 